\title{
Aplikasi DIY Smart Trash berbasis IoT Open Platform
}

\section{Rizqi Putri Nourma Budiarti ${ }^{*}$, Jordan Maulana² dan Sritrusta Sukaridhoto ${ }^{3}$}

\author{
${ }^{1}$ Sistem Informasi, Fakultas Teknik, Universitas Nahdlatul Ulama Surabaya, Surabaya \\ ${ }^{2}$ E-Business, Marketing, PT. Sinergi Informatika Semen Indonesia, Gresik \\ ${ }^{3}$ Departemen Multimedia Kreatif, Politeknik Elektronika Negeri Surabaya, Surabaya \\ *E-mail: rizqi.putri.nb@unusa.ac.id
}

\begin{abstract}
Abstrak
Sampah merupakan hal yang tidak asing lagi bagi manusia saat ini. Bagi orang-orang yang tidak bertanggung jawab akan berfikir bahwa sampah dapat dibuang dimana saja, bahkan ada yang meletakkan sampah dengan mudahnya sambil meninggalkan sampah tersebut secara sembarangan tanpa berpikir bahwa ada tempat sampah yang layak dan sesuai dengan peruntukannya. Ketidaksadaran dalam membuang sampah secara sembarangan inilah yang dapat merusak pemandangan di area sekitar tempat itu. Saat ini, sangat banyak produk-produk sampah yang pintar di pasaran dalam memecahkan permasalahan sampah bahkan memudahkan pemiliknya. Namun, produknya sangat mahal dan biasanya setiap orang sudah menyediakan tempat sampahnya sendiri dirumah. Oleh karena itu, kami mengusulkan sebuah aplikasi DIY (Do It Yourself) Smart Trash berbasis IoT (Internet of Things) Open Platform. Aplikasi DIY Smart Trash dengan IoT Open Platform ini terdiri dari platform terbuka yang menyediakan monitoring web dan visualisasi interaktif yang ditampilkan dalam dashboard, layanan MQTT (MQ Telemetry Transport), Kafka, database untuk menerima data dan push notification untuk dapat memberitahukan kepada pengguna. Kami juga mnggunakan sistem embedded dan menyediakan source code untuk Arduino, Redbear, Raspberry Pi3 dan Raspberry Pi Zero $W$ untuk membangun DIY Smart Trash. Dengan menggunakan aplikasi DIY Smart Trash, secara tidak langsung dapat mengurangi biaya manajemen sampah di setiap rumah. Selain itu dari segi harga, DIY Smart Trash memiliki harga yang lebih terjangkau daripada yang lain.
\end{abstract}

Kata Kunci: DIY Smart Trash, Internet of Things, Open Platform, Pemantauan Sampah, Manajemen Sampah.

\section{PENDAhuluan}

Pengelolaan manajemen sampah sangat diperlukan masyarakat saat ini, dengan adanya keberadaan bank sampah yang tersedia diberbagai lokasi, diharapkan mampu merubah budaya masyarakat untuk membuang sampah pada tempatnya dan mulai turut andil dalam pengelolaan sampah. Pengelolaan sampah dapat dimulai dari lingkungan sekitar kita, di setiap rumah biasanya sudah tersedia tempat pembuangan sampah yang biasanya sudah ada dan berada di depan rumah tiap masyarakat. Namun selama ini tempat sampah yang ada masih belum dalam kategori "Smart Trash" atau tempat sampah pintar yang bisa memberitahukan pemilik atau orang yang berwenang terhadap sampah itu bahwa sampahnya dalam keadaan penuh dan harus segera dibuang. Selain itu, bagi masyarakat perkotaan yang mobilitasnya tinggi sering kali terlupa untuk membuang sampah dapurnya ke tempat pembuangan sampah akhir sehingga secara tidak langsung membuat kondisi rumah yang ditempati menjadi bermasalah dengan bau dan sumber penyakit. Walaupun sebenarnya mereka sudah memiliki kesadaran untuk membuang sampah di tempat sampah yang tersedia.

Kata "Sampah" diambil dari definisinya sesuai UU No.18 Tahun 2008, merupakan sisa hasil dari kegiatan manusia sehari-hari dan/atau proses alam yang berbentuk padat dimana 
pengelolaannya secara teknis dari kegiatan yang sistematis, menyeluruh dan berkesinambungan yang dapat mengurangi, menangani dan melakukan pemanfaatan sampah (Indonesia, 2008). Pemerintah pun mengharapkan agar dalam kegiatan pengelolaan sampah, masyarakat dapat berperan aktif maupun berperan secara pasif karena sebagian besar penghasil limbah adalah masyarakat. Beberapa contoh sampah yang sering dihasilkan masyarakat diantaranya sisa makanan, sampah kertas, gelas, kaca, plastik, kaleng, logam, kardus, barang bekas, sampah limbah seperti sampah limbah baterai, sampah limbah oli, sampah limbah obat-obatan (limbah medis lainnya), dll.

Dalam pengelolaan sampah pada masyarakat, upaya pemerintah untuk menyediakan dan memfasilitasi teknologi terapan yang ramah lingkungan, dimana masyarakat bisa merasakan dampak dari pengurangan sampah secara langsung. Teknologi yang dikembangkan diharapkan mampu mengurangi berbagai permasalahan sampah yang secara langsung dapat mengganggu lingkungan dan secara tidak langsung juga dapat mengganggu pelayanan masyarakat salah satunya adalah apabila sampah dibuang sembarangan misalkan di sungai yang dijadikan sebagai sumber air baku masyarakat bisa berakibat pada gangguan prasarana dalam pelayanan pemerintah terhadap persediaan air bersih baik di pedesaan maupun perkotaan.

Oleh karena itu, pengelolaan manajemen sampah memainkan peran penting selain karena kompleksitas dari masalah sampah yang akan muncul baik dapat mengganggu kesehatan masyarakat. Hal ini juga dapat menghambat perkembangan sektor-sektor strategis di suatu negara. Sebagai pertumbuhan penduduk telah meningkat, limbah yang dihasilkan juga meningkat. Seringkali, masalah dalam manajemen sampah disebabkan oleh peralatan yang terbatas, keterbatasan dana dan sumber daya manusia yang terbatas. Meskipun manajemen sampah, biasanya dimulai dari pengumpulan sampah, penghapusan, transportasi dan proses pembuangan ke TPA (Tempat Pembuangan Akhir).

Kebiasaan yang kadang kita jumpai seringkali orang-orang yang masih mengotori dan bahkan terlupa untuk membuang sampah dapur mereka di pembuangan sampah utama. Seiring dengan berjalannya waktu, diharapkan kesadaran dan partisipasi masyarakat dapat meningkat secara bertahap, terutama dalam pengelolaan sampah sehingga sampah yang harus ditangani secara efisien untuk mengurangi dampak lingkungan. Dampak lingkungan yang bisa membahayakan kehidupan manusia dapat dikurangi dengan berbagai upaya masyarakat yang peduli terhadap lingkungan sekitarnya. Berikut beberapa contoh upaya masyarakat untuk mengurangi dampak lingkungan dapat dilihat sebagai beberapa orang membuat aplikasi untuk mengelola sistem pemantauan kualitas air untuk pengolahan air dengan menggunakan Web Scraping (Budiarti dkk., 2016) dan menciptakan sistem monitoring yang mampu melakukan klasifikasi kualitas air secara interaktif sebagai peringatan awal menggunakan SVM (Support Vector Machines) untuk identifikasi persediaan air pada airbaku (Rizqi Putri Nourma Budiarti, 2016).

Untuk membantu manajemen sampah ada banyak produk sampah pintar di pasar. Berikut contoh penggunaan tong sampah pintar diantaranya Bruno, Temboo dan lab Ecube. Bruno menyediakan tong sampah pintar yang membersihkan debu yang berada di depan alat ini secara otomatis. Temboo mendukung pemantauan melalui aplikasi android dan dilengkapi kalender untuk membantu pengguna mengingat terakhir kali mereka membersihkan sampahnya. Ecube lab menyediakan sistem pemantauan sampah untuk memberitahu setiap kali sampah pintar penuh. Namun, beberapa contoh dari penggunaan tong sampah pintar yang terkenal berawal dari memiliki permasalahan yang sama. Mereka terlalu mahal untuk diterapkan di Indonesia. Para pengguna juga harus membeli tempat sampah pintar yang baru walaupun sebenarnya mereka memiliki tong sampah yang lama di rumah walaupun belum dikategorikan sebagai tong sampah pintar. Para pengguna harus berlangganan untuk mendapatkan layanan notifikasi dan membayar 
sejumlah uang dalam penggunaan aplikasi tong sampah pintarnya. Kami mengusulkan IoT Open Platform untuk DIY "Smart Trash" istilah yang digunakan untuk penggunaan tong sampah pintar dengan konsep platform IoT Terbuka dan DIY-Do It Yourself dimana masyarakat bisa membuatnya secara mandiri dan memasangnya sendiri. Kami juga mnggunakan sistem embedded dan menyediakan source code untuk Arduino, Redbear, Raspberry Pi3 dan Raspberry Pi Zero $W$ untuk membangun IoT Open Platform DIY Smart Trash. Dalam mengusulkan sistem ini, kita menggunakan Raspberry Pi Nol $W$ sebagai sistem embedded. IoT Open Platform untuk DIY Smart Trash terdiri dari:

- Plat Platform Layanan dari Server yang menyediakan monitoring web dan visualisasi interaktif, dashboard, layanan MQTT, Kafka, database dan push notification.

- Paket perangkat lunak seperti untuk sistem embedded (Arduino, Redbear, Raspberry Pi3 dan Raspberry Pi Zero $W$ ) dengan fungsi menghubungkan ke jaringan Wi-Fi, menghitung jarak dari sensor ultrasonik dan mengirim data melalui protokol MQTT.

- Aplikasi Android DIY Smart Trash, terdiri dari peta posisi tong sampah dan sistem notifikasi.

MQTT (MQ Telemetry Transport) merupakan protokol pengiriman pesan yang sangat sederhana dimana hanya dirancang untuk mempublikasikan maupun berlangganan pesan dengan meminimalkan penggunaan bandwidth jaringan dan kebutuhan sumber daya perangkat terutama penggunaan aplikasi untuk IoT (Internet of Things).

Telah banyak penelitian yang dilakukan seputar implementasi pada penggunaan tong sampah pintar sebagai upaya pengelolaan sampah yang otomatis. Beberapa diantaranya adalah Penelitian yang dilakukan oleh Adil Bashir, Shoaib A, Ab. Rouf K, dan Mohammad S (Bashir dkk., 2013) dimana konsep, desain dan implementasi sistem pengelolaan sampah otomatis. Mereka merancang sebuah metode untuk mengawasi limbah dengan cara yang efisien untuk meminimalkan pemanfaatan sumber daya seperti usaha manusia, waktu dan biaya. Penggunaan sistem sampah cerdas ini dikenal sebagai Smart Trash Bin, yang terdiri dari sensor dan transmitter radio frekuensi (RF). Smart Trash Bin mengumpulkan status limbah diukur oleh sensor. Terdapat dua jenis sensor yang digunakan di Smart Trash Bin. Sensor yang pertama adalah sensor beban yang digunakan untuk mengukur beban sampah di tempat sampah dan yang kedua adalah sensor jarak IR yang berfungsi untuk mendeteksi tingkat limbah di tempat sampah pintar. Pada penggunaan sensor IR digunakan dua buah sensor IR, satu sensor ditempatkan di tengah Smart Trash Bin dan yang kedua ditempatkan di dekat bagian atas Smart Trash Bin. Penggunaan pada kedua sensor IR bertujuan untuk membuat keputusan yang lebih handal dan tepat.

Penelitian lain yang telah dilakukan, salah satunya adalah penelitian dari Sandeep, Shriram, Akshay, Namrata dan Rohini (Chaware dkk., 2007) dimana pembuatan sistem pemantauan dengan tong sampah pintar yang menggunakan Internet of Things. Sistem Internet of Things ini menggunakan sensor ultrasonik diletakkan di posisi atas untuk mendeteksi tingkat ketinggian sampah. Sistem ini menggunakan Arduino mikrokontroler, layar LCD dan wifi modem untuk mengirimkan data menuju ke web server dan menampilkannya ke halaman web yang dibangun untuk mengetahui dan memantau penggunaan user dan memberikan tampilan grafis dari sampahsampah dan menginformasikan sampah yang dikumpulkan dalam warna untuk mengetahui status tingkat sampah yang dikumpulkan. Status tingkat sampah ini dapat dilihat melalui layar LCD. Sistem ini juga menempatkan bel sehingga berbunyi ketika tingkat sampah yang dikumpulkan melintasi batas yang telah ditentukan.

Selain itu, penelitian lainnya dilakukan oleh Herwindra (Berlian dkk., 2016). Penelitian mereka membangun sebuah platform Internet of Things untuk pemantauan lingkungan. Dimana 
pada penelitian ini kami juga membangun hal serupa namun dikhususkan untuk lokasi dan kondisi aplikasi DIY Smart Trash.

Struktur paper ini disusun sebagai berikut: Pada bagian pertama berisikan pendahuluan. Bagian berikutnya menguraikan metodologi penelitian. Pada bagian ketiga menjelaskan hasil dan pembahasan dimana memaparkan hasil eksperimen yang dilakukan yaitu aplikasi DIY Smart Trash berbasis IoT Open Platform. Pada Bab terakhir menyajikan kesimpulan dari hasil percobaan.

\section{METODOLOGI}

\subsection{Tahapan dalam penelitian}

Pada metode penelitian ini menjelaskan mengenai tahapan - tahapan yang digunakan dalam penelitian yang dilakukan. Pada penelitian ini menunjukkan tahapan atau alur pelaksanaan penelitian seperti yang digambarkan pada Gambar 4.

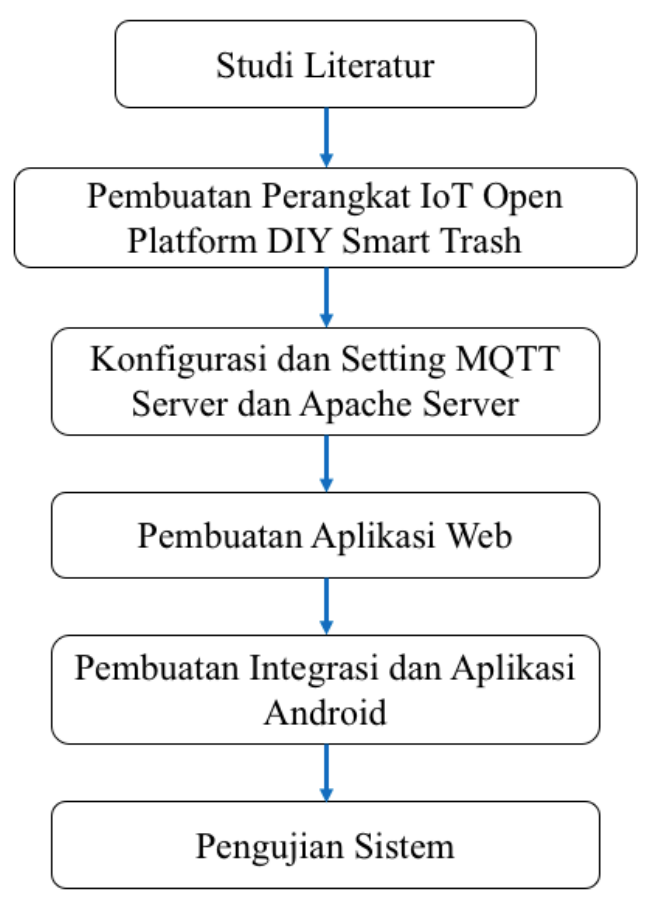

Gambar 4. Metodologi Penelitian

\subsubsection{Studi literatur}

Pada tahap ini dilakukan studi literatur dalam mempelajari penelitian-penelitian terkait dan yang dibutuhkan baik mengenai hardware, software dan hal-hal yang diperlukan dalam membangun sistem yang akan dibuat.

\subsubsection{Pembuatan Perangkat IoT Open Platform DIY Smart Trash}

Pada tahap ini dilakukan pembuatan perangkat IoT (Internet of Thing) DIY (Do It Yourself) Smart Trash yang terdiri dari sensor ultrasonic HC-SR04 yang dihubungkan ke sistem benam Raspberry Pi Zero W yang dilengkapi dengan perangkat lunak (OS Raspbian) yang digunakan sebagai unit pemrosesan data dari sensor dan mengirimkan data ketinggian jarak. Desain perangkat sensor dapat dilihat pada Gambar 5. 


\subsubsection{Pembuatan Aplikasi Web}

Pada tahap ini dilakukan pembuatan aplikasi web yang memfasilitasi monitoring dan pemetaan area penggunaan DIY Smart Trash.

\subsubsection{Pembuatan Integrasi dan Aplikasi Android}

Pada tahap ini dilakukan pembuatan aplikasi android yang diintegrasikan dengan sistem perangkat IoT Open Platform DIY Smart Trash dan Apache Kafka untuk push-notifikasi dalam memberikan informasi kondisi sampah sudah penuh.

\subsubsection{Pengujian Sistem}

Pada tahap ini dilakukan pengujian terhadap sistem yang telah dibuat apakah dapat bekerja dengan baik.

\subsection{Desain Sistem}

Arsitektur desain sistem keseluruhan pada IoT Open Platform DIY Smart Trash dapat dilihat pada Gambar 5. Dimana sebagai contoh dalam desain sistem yang digambarkan untuk perangkat mikro embedded system yang digunakan, salah satunya adalah Raspberry Pi Zero W.

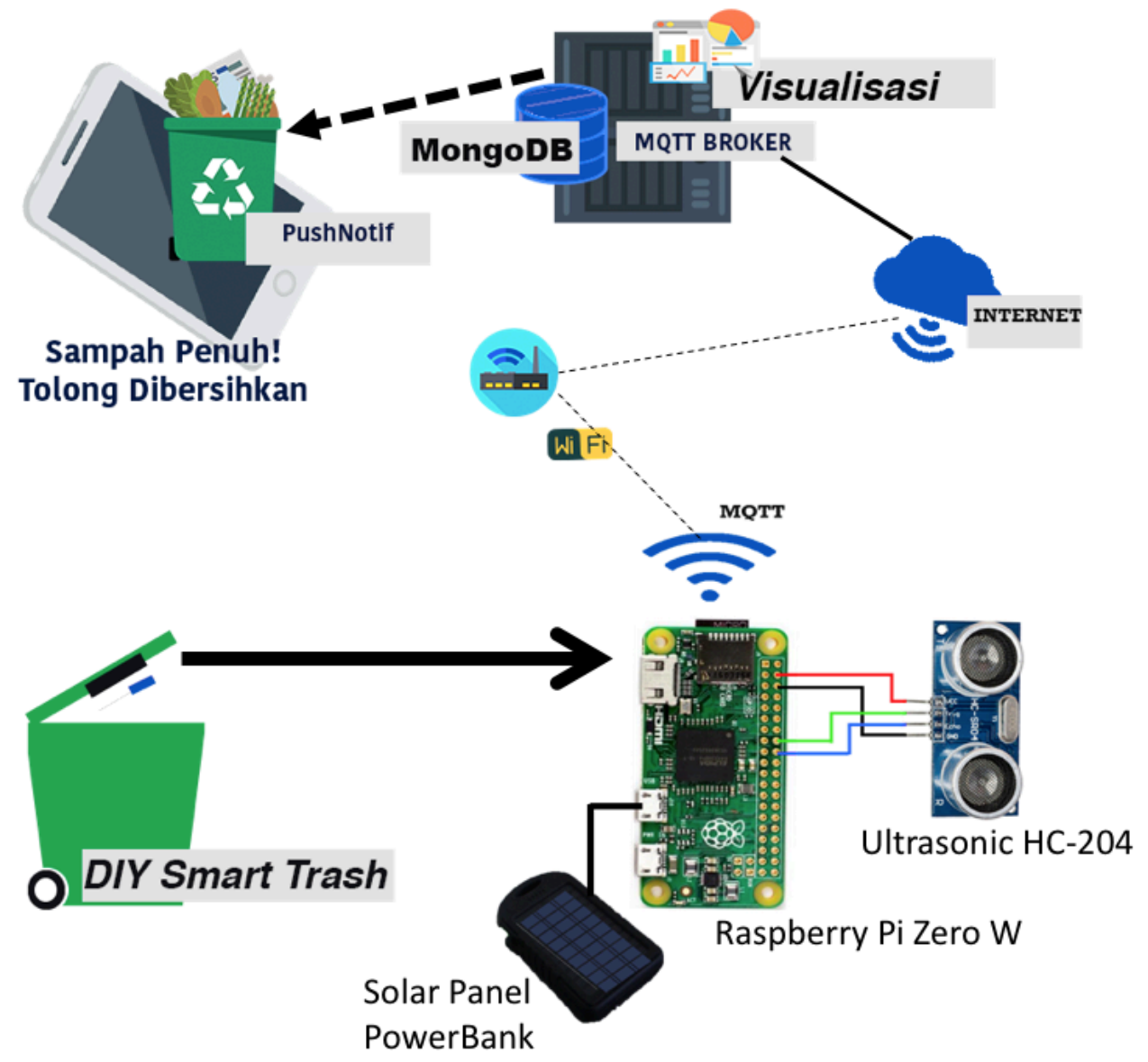

Gambar 5. Arsitektur Desain Sistem pada DIY Smart Trash

Pada arsitektur desain sistem pada DIY Smart Trash, perangkat sensor yang dibuat diletakkan pada bagian bawah penutup tempat sampah. Sehingga sensor bisa mengukur isi pada tong sampah berdasarkan tingkat ketinggian pada tempat sampah yang digunakan. Apabila sampah yang terkumpul sudah dikategorikan sebagai tempat sampah dalam kondisi penuh, maka secara otomatis akan mengirimkan pesan ke MQTT broker untuk meneruskan pesan kepada pemilik atau 
pengguna tempat sampah dan memberitahukan informasi bahwa sampah dalam kondisi penuh dan harus segera dibuang. Aplikasi DIY Smart Trash menggunakan Android Apps.

Sensor yang digunakan dalam pengukuran ketinggian sampah adalah menggunakan HC-SR04 Ultrasonic Sensor yang merupakan sensor proximity sering diistilahkan dengan sensor jarak yang sangat terjangkau dan sering digunakan terutama untuk mengukur jarak ke suatu objek. HC-SR04 sensor ultrasonik menggunakan sonar untuk menentukan jarak ke objek seperti halnya yang dilakukan kelelawar. Sensor sonar ini menawarkan deteksi berbagai non-kontak yang sangat baik dengan akurasi tinggi dan pembacaan yang stabil dalam paket yang mudah digunakan. Dari $2 \mathrm{~cm}$ $400 \mathrm{~cm}$ atau 1 sampai 13 kaki. Dalam pengoperasian alat ini tidak terpengaruh oleh sinar matahari atau bahan hitam seperti pengukur jarak Sharp (meskipun akustik bahan lembut seperti kain bisa sulit untuk mendeteksi). Perangkat ini dilengkapi dengan pemancar ultrasonik dan modul penerima. The Ultrasonic Sensor mengirimkan suara pulsa frekuensi tinggi dan kemudian dalam berapa waktu lamanya yang dibutuhkan untuk menghasilkan gema suara sehingga merefleksikan kembali. Sensor ini memiliki dua bukaan di depan. Bukaan yang pertama digunakan untuk mentransmisikan gelombang ultrasonik, (seperti speaker kecil), yang lain hanya menerima mereka, (seperti mikrofon kecil). Kecepatan suara adalah sekitar 341 meter (1.100 kaki) per detik di udara. Sensor ultrasonik menggunakan informasi ini bersama dengan perbedaan waktu antara pengiriman dan penerimaan pulsa suara untuk menentukan jarak ke obyek. Arsitektur dari HCSR04 Ultrasonic Sensor seperti yang digambarkan pada Gambar 6 sebagai berikut.

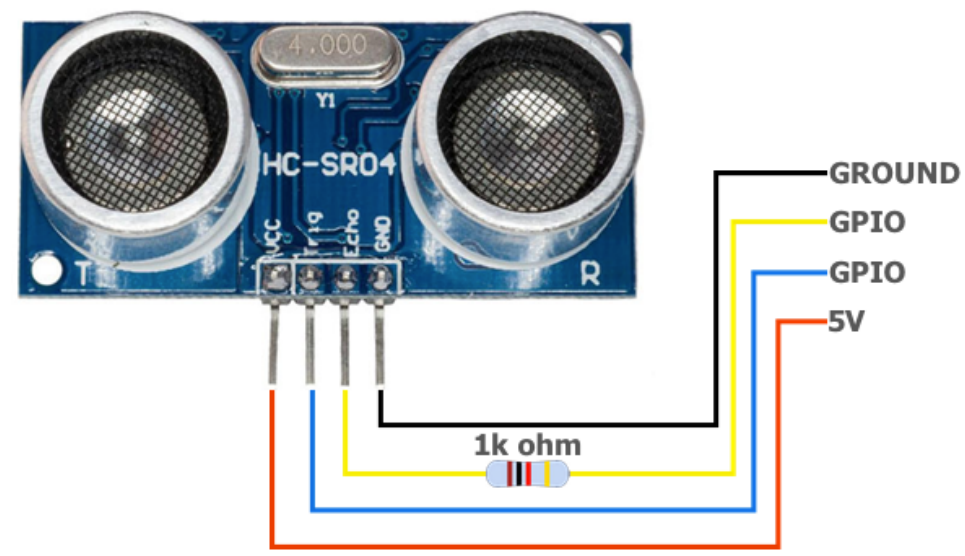

Gambar 6. Arsitektur dari HC-SR04 (sumber: https://github.com/mochman/MMM-Swipe)

Pada penelitian ini, spesifikasi server yang digunakan untuk database dan aplikasi platform dapat dilihat pada Tabel 11:

Tabel 11. Spesifikasi Server untuk IoT Open Platform

\begin{tabular}{|l|l|}
\hline Kategori & Keterangan \\
\hline CPU & Intel(R) Xeon(R) CPU E3-1220 v3@3.10GHz \\
\hline Core & 4 \\
\hline RAM & $4 \mathrm{~GB}$ \\
\hline HDD & $500 \mathrm{~GB}$ \\
\hline Internet Connection & 20Mbps \\
\hline
\end{tabular}

Komunikasi antara perangkat fisik dan server menggunakan Wi-fi. MQTT server dibangun untuk membuat sambungan antara perangkat fisik dan database sehingga data disimpan dalam basis data MySQL. Komunikasi antara sensor dan server menggunakan protokol MQTT, 
pengiriman data dikirim secara real time. Format data yang kami gunakan adalah JSON. Ketika MQTT broker menerima data dari sensor, MQTT melakukan publish data untuk Kafka broker menggunakan topik yang telah ditetapkan. Lapisan aplikasi subsciber data dari Kafka broker menggunakan data untuk menganalisis jarak dari sensor. Jika data jarak sampah kurang dari 10 $\mathrm{cm}$, Kafka melakukan pembaharuan data sampah pada database. Setelah menyimpan ke database pesan diteruskan ke web client menggunakan WebSocket untuk memvisualisasikan jarak sampah dan mengirimkan notifikasi secara real time. Data untuk push notification akan ditempatkan dan divisualisasikan di web. Dashboard akan melakukan subscribe untuk memvisualisasikan posisi DIY Smart Trash dalam peta dan menampilkan diagram ketinggian isi sampah vs waktu dari DIY Smart Trash. DIY Smart Trash juga dapat menemukan rute tercepat untuk sampah mengumpulkan truk untuk menghemat waktu dan uang dalam cara yang lebih murah. Untuk lebih jelasnya diagram blok ditunjukkan oleh Gambar 7.

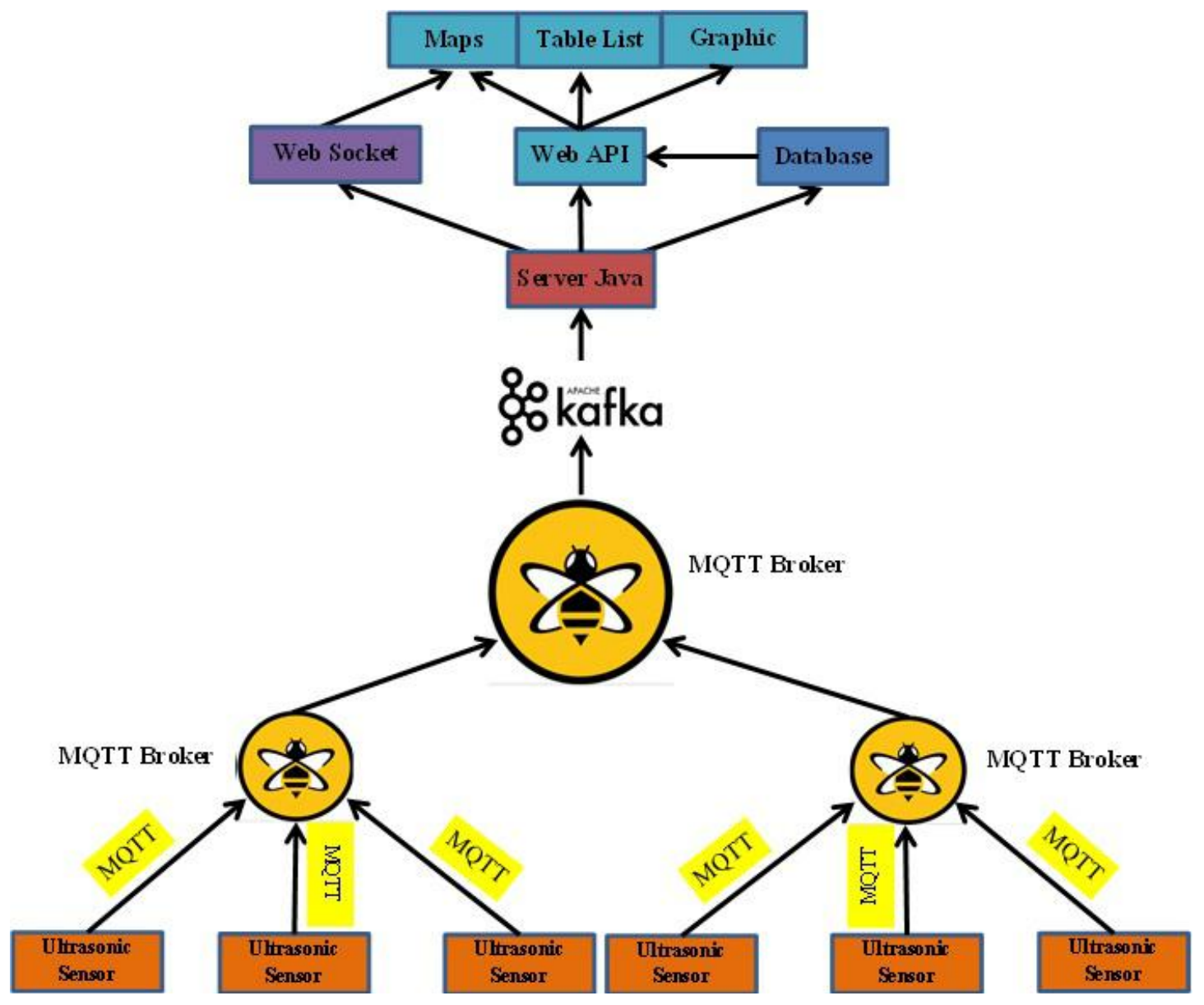

Gambar 7. Komunikasi data menggunakan MQTT dan Kafka

\section{HASIL DAN PEMBAHASAN}

Pada penelitian ini, difokuskan pada pembuatan perangkat IoT Open Platform, pembangunan edge computing dari sisi pengguna untuk DIY Smart Trash serta Aplikasi Android untuk memudahkan pengguna DIY Smart Trash. Untuk perangkat IoT open platform yang terpasang pada penutup DIY Smart Trash dapat dilihat pada Gambar 8 sebagai berikut: 


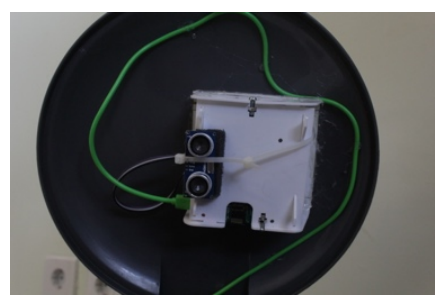

Gambar 8. Perangkat DIY Smart Trash pada penutup tempat sampah

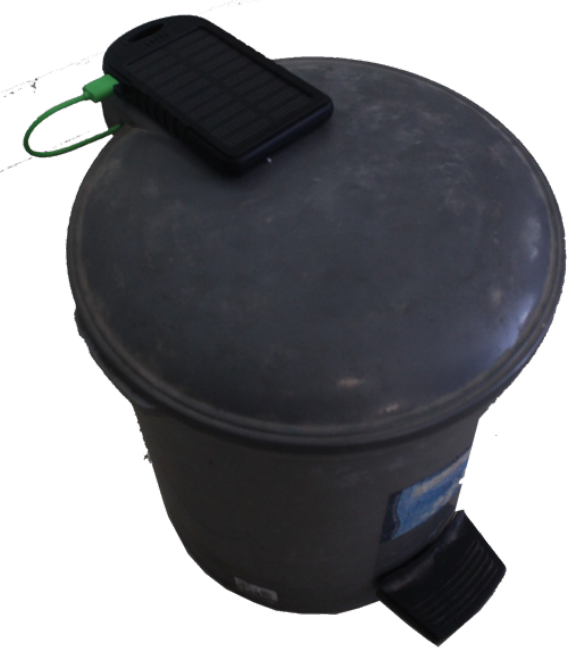

Gambar 9. Implementasi pada IoT Open Platform DIY Smart Trash
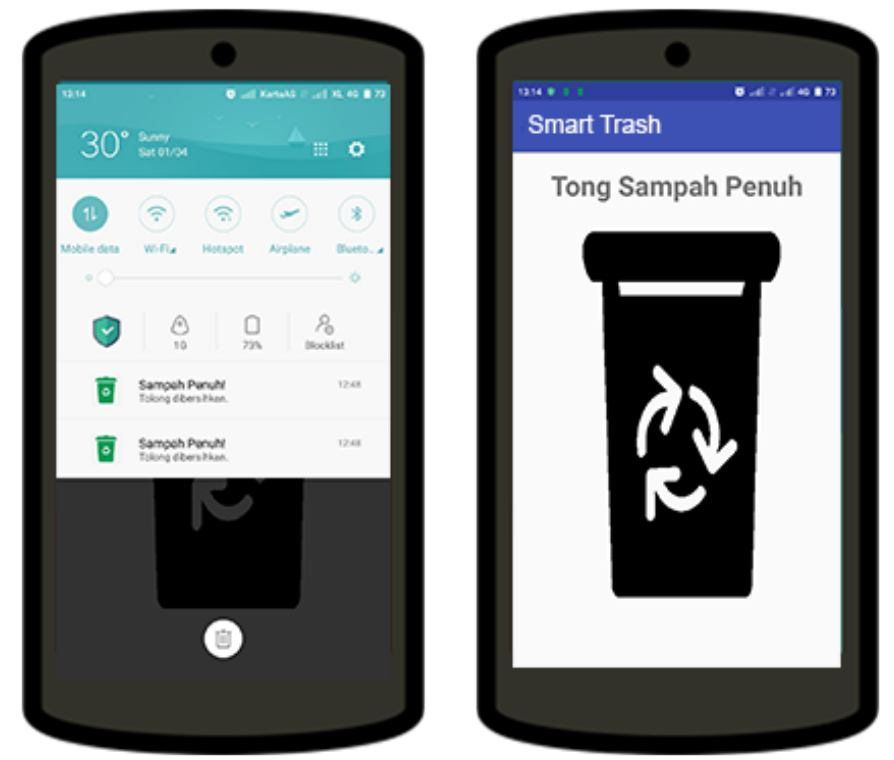

Gambar 10. Tampilan Aplikasi pada Android Apabila Sampah Penuh

Pada implementasi IoT Open Platform DIY Smart Trash yang dapat dilihat pada Gambar 9 dan Gambar 10, pemilik atau pengguna yang bertanggungjawab terhadap tempat sampah yang telah dipasang perangkat IoT Open Platform DIY Smart Trash dimana no. handphone pengguna 
tempat sampah inilah yang tercatat ke dalam database dan menerima report penggunaan tempat sampahnya. Implementasi DIY Smart Trash disediakan untuk masyarakat yang nantinya bisa men-develop sendiri tempat sampahnya menggunakan tempat sampah yang ada di rumah atau yang sudah dimilikinya dan menjadikannya smart. Dengan DIY Smart Trash, membuat dan mendownload serta menginstall aplikasi Smart Trash yang telah dibuat pada Google Apps. Penggunaan IoT Open Platform ini tidak memakan biaya yang cukup besar. Dimana rata-rata pengeluaran untuk biaya perangkat ini adalah $\$ 61,76$ atau sekitar $\mathrm{Rp} 926.400,-$.

Masing-masing DIY Smart Trash memiliki ID unik. Setelah simulasi dan implementasi dari DIY Smart Trash di beberapa titik daerah Surabaya. Selama 1 minggu kami mendapatkan hasil sebagai berikut pada Gambar 11.

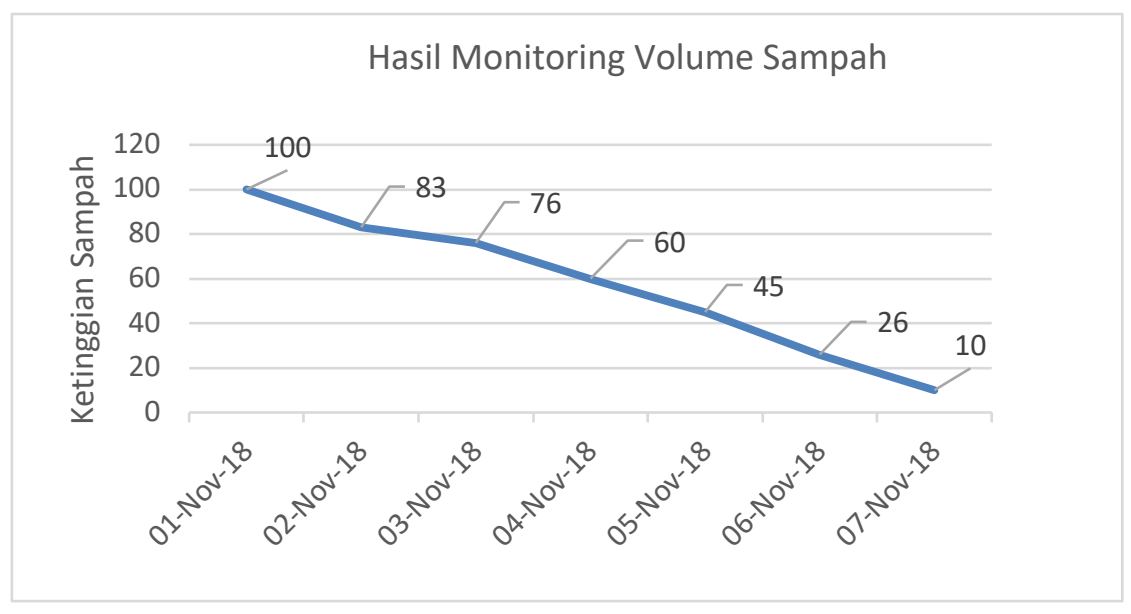

Gambar 11. Grafik Monitoring Sampah

Pada hari pertama dengan kondisi sampah kosong di mana sensor jarak ultrasonik adalah ketinggian tempat sampah. Pada hari kedua 2018/11/02 ada perubahan ketinggian volume sampah yang mengakibatkan jarak antara sensor ultrasonik dan tinggi sampah berubah menjadi $83 \mathrm{~cm}$. Pada hari berikutnya 2018/11/03, ultrasonik sensor jarak ke $76 \mathrm{~cm}$. Ketika jarak kurang dari 10 $\mathrm{cm}$ maka monitoring web akan muncul notifikasi bahwa tong sampah penuh. Ketika sampah sudah penuh maka peta akan muncul gambar tong sampah berwarna merah. Sementara gambar dari tong sampah hitam dapat menunjukkan bahwa sampah belum dapat terisi penuh. Peta ditunjukkan pada Gambar 12 dan Gambar 13.

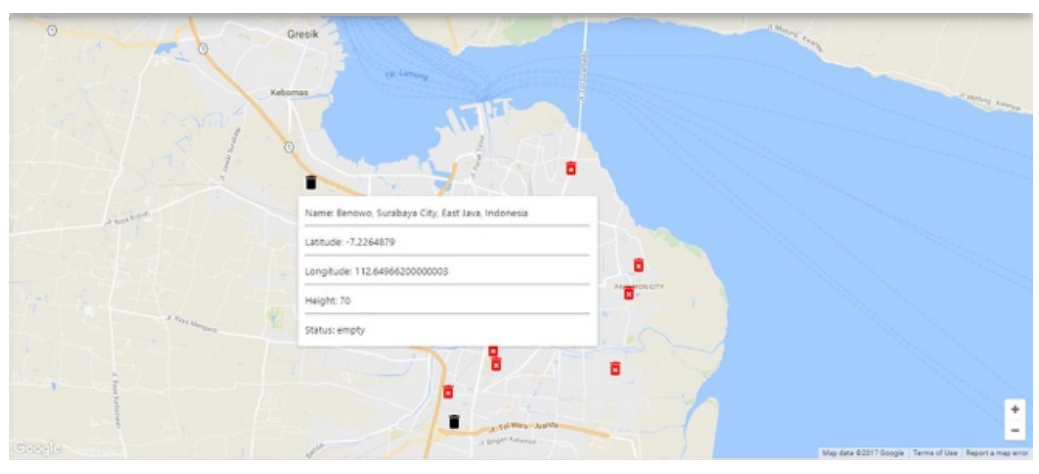

Gambar 12. Kondisi Ketika Sampah Kosong di Maps 


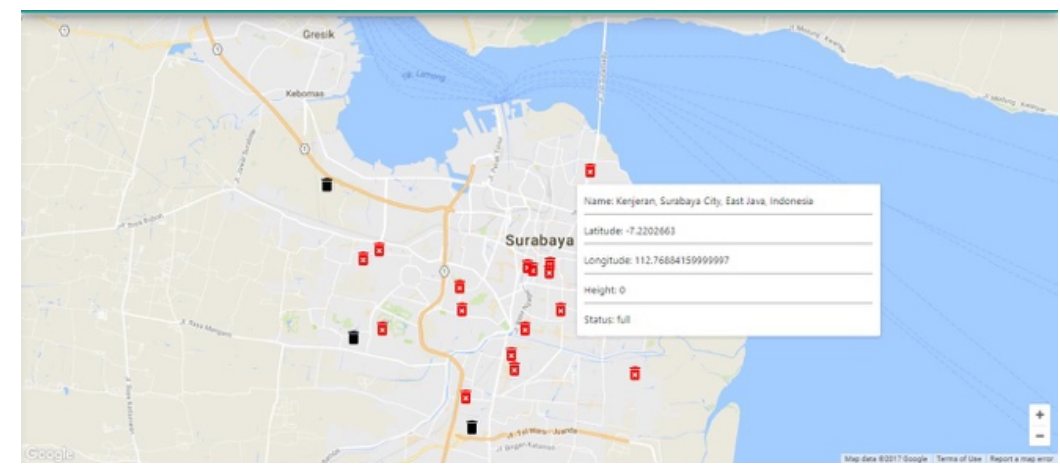

Gambar 13. Kondisi Ketika Sampah adalah penuh di Maps

Aplikasi web DIY Smart Trash memiliki pengguna dan admin izin, hak akses sebagai pengguna hanya dapat mengakses informasi posisi seluruh sampah dan keadaan volume sampah, sedangkan hak akses sebagai admin memiliki fasilitas menambahkan pengguna baru, hak istimewa admin juga bisa meningkatkan dan mengurangi jumlah sampah sampah di masingmasing daerah. Penambahan sampah dapat diperbarui secara otomatis dalam daftar sampah yang terletak di kota Surabaya. Fitur yang disediakan mencakup pemantauan sampah di masing-masing daerah dengan peta menampilkan, Daftar list sampah, Data History sampah.

Pada Gambar 14 menampilkan daftar sampah. Daftar sampah berisi data mana sampah ditempatkan.

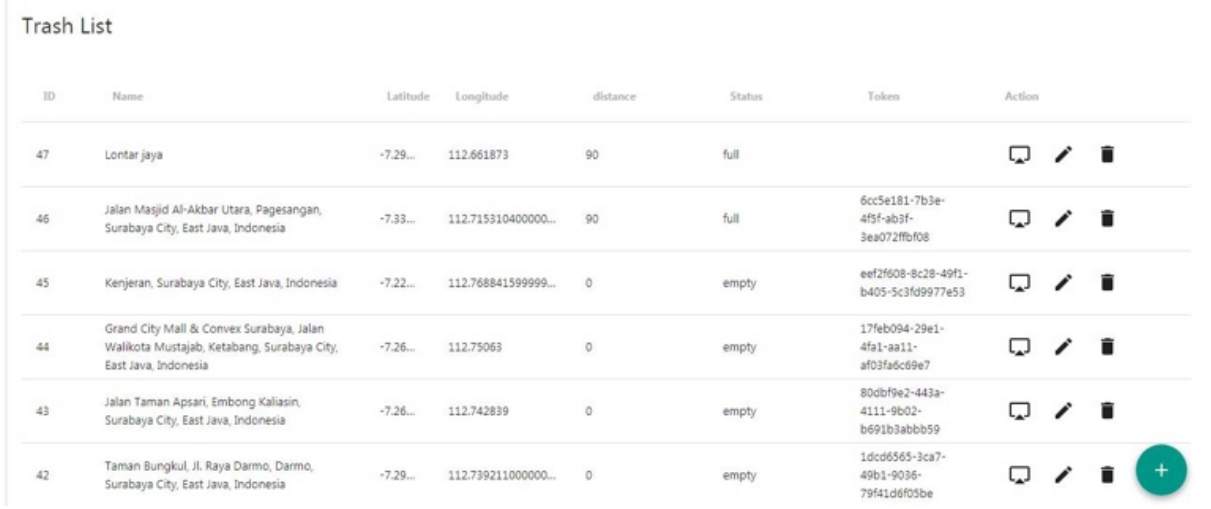

Gambar 14. Daftar list Sampah

Data history sampah memiliki fitur untuk volume sampah auto-update di setiap daerah yang memiliki tempat sampah. Data history Sampah memiliki tujuan untuk pengguna DIY Smart Trash untuk tahu kapan sampah dikosongkan. Data history Sampah ditunjukkan pada Gambar 15.

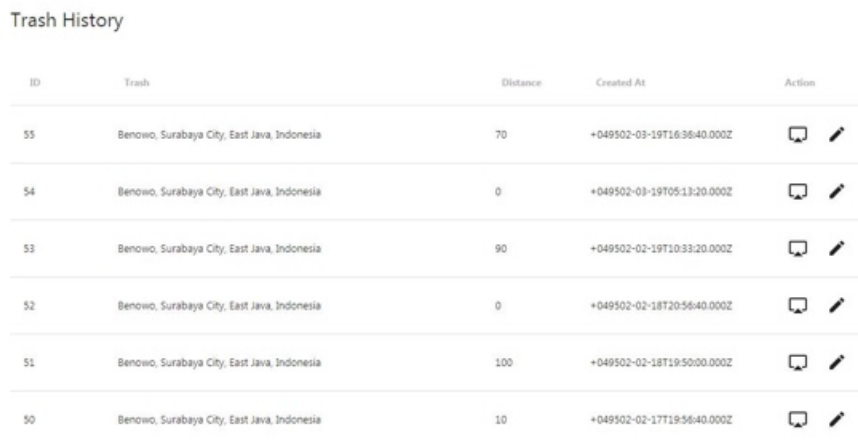

Gambar 15. Data History Sampah 
Dari segi harga, DIY Smart Trash memiliki harga yang lebih terjangkau daripada yang lain. Berikut adalah perbandingan perkiraan harga antara DIY Smart Trash dengan produk smart tempat sampah lainnya yang ditunjukkan oleh Tabel 12.

Tabel 12. Perbandingan Harga dengan Smart Tempat Sampah Lain

\begin{tabular}{|l|l|}
\hline Alat & Harga \\
\hline Bruno & $\$ 229$ \\
\hline Temboo & $\$ 129$ \\
\hline lab Ecube & $\$ 1300-1700$ \\
\hline DIY Smart Trash & $\$ 61,76$ \\
\hline
\end{tabular}

DIY Smart Trash memiliki harga \$61,76 dengan rincian harga perangkat yang diperlukan seperti pada Tabel 13 .

Tabel 13. Rincian Harga DIY Smart Trash

\begin{tabular}{|l|l|}
\hline DIY Smart Trash Perangkat & Harga \\
\hline $\begin{array}{l}\text { Raspberry Pi Zero W Set } \\
\text { (dengan casing) }\end{array}$ & $\$ 34,90$ \\
\hline $\begin{array}{l}\text { Sensor ultrasonic } \\
\text { HC-SR04 }\end{array}$ & $\$ 3,95$ \\
\hline $\begin{array}{l}\text { Kabel Jumper } \\
\text { Kabel F / F }\end{array}$ & $\$ 1,91$ \\
\hline PowerBank Panel Surya & $\$ 21,23$ \\
\hline Jumlah total & $\$ 61,76$ \\
\hline
\end{tabular}

\section{KESIMPULAN}

Pada IoT Open Platform untuk DIY Smart Trash ini sangat cocok untuk aplikasi smart city di bidang pengelolaan sampah. Semua aplikasi ini user friendly bahkan dalam aplikasi web ataupun android. Biaya perangkat hardware yang dibutuhkan dalam men-develop IoT Open Platform DIY Smart Trash ini jauh lebih murah daripada membeli perangkat tempat sampah pintar lainnya. Selain itu, Berdasarkan hasil eksperimen yang dilakukan, sistem IoT Open Platform DIY Smart Trash dapat mengirimkan notifikasi ke pengguna. Hal ini membuktikan sistem IoT Open Platform DIY Smart Trash telah berjalan dengan baik. Untuk pengembangan selanjutnya, masih diperlukan fitur-fitur tambahan seperti penggunaan Business Analytics pada masing-masing IoT Open Platform DIY Smart Trash yang dibangun. IoT Open Platform DIY Smart Trash diharapkan mampu memberikan kinerja yan baik dan bermanfaat.

\section{DAFTAR PUSTAKA}

[1] R. Indonesia. Pengelolaan Sampah. Jakarta: Sekretariat Negara. 2008.

[2] R. P. N. Budiarti, N. Widyatmoko, M. Hariadi, dan M. H. Purnomo. Web scraping for automated water quality monitoring system: A case study of PDAM Surabaya. In 2016 International Seminar on Intelligent Technology and Its Applications (ISITIA). 2016; 641-648.

[3] R. P. N. Budiarti. Klasifikasi Air Sungai Berbasis Kombinasi Teknologi Iot-Big Data Menggunakan SVM. Thesis. Surabaya: Institut Teknologi Sepuluh Nopember. 2016.

[4] MQTT-MQ Telemetry Transport, http://mosquitto.org/man/mqtt-7.html diakses tanggal 8 
november 2018.

[5] A. Bashir, S. A. Banday, A. R. Khan, dan M. Shafi. Concept, Design and Implementation of Automatic Waste Management System. International Journal on Recent and Innovation Trends in Computing and Communication. 2013. ISSN 2321-8169.

[6] S. M. Chaware, S. Dighe, A. Joshi, N. Bajare, dan R. Korke. IJIREEICE IJIREEICE Smart Garbage Monitoring System using Internet of Things (IOT). Int. J. Innov. Res. Electr. Electron. Instrum. Control Eng. ISO. 2007; 3297(1). ISSN 2321-5526.

[7] M. H. Berlian, T. E. R. Sahputra, B.J. Wahana Ardi, L.W., Dzatmika, A. R. A. Besari, R.W. Sudibyo, S. Sukaridhoto. Design and implementation of smart environment monitoring and analytics in real-time system framework based on internet of underwater things and big data. In 2016 International Electronics Symposium (IES). 2016; 403-408.

[8] Arsitektur HC-SR04, https://github.com/mochman/MMM-Swipe diakses tanggal 10 november 2018. 